\title{
Correlation of Serological and Biochemical Groupings of Yersinia enterocolitica with the $\beta$-Lactamases of the Strains
}

\author{
By MARGARET MATTHEW \\ Microbiology Division, Glaxo Research Limited, Greenford UB6 oHE, Middlesex \\ G. CORNELIS AND G. WAUTERS \\ Department of Microbiology, University of Louvain, BI 200 Brussels, Belgium
}

(Received I6 February 1977; revised 22 April 1977)

The $\beta$-lactamase isoelectric focusing patterns of 37 strains of Yersinia enterocolitica from various serological and biochemical groups were examined. Strains of different serological groups generally had different patterns, but those of serological groups I, 2, 3 and 9 were identical.

\section{INTRODUCTION}

The species Yersinia enterocolitica includes strains that are heterogeneous (Wauters, 1970, I973); five biochemical types have been defined (Niléhn, I969; Wauters, I970, I973), and up to 34 O-antigenic factors have been recognized (Wauters, Le Minor \& Chalon, 197I; Wauters et al., 1972; Winblad, 1967, 1968). All $Y$. enterocolitica strains examined by Cornelis, Wauters \& Vanderhaeghe (I973) produced $\beta$-lactamase (EC 3.5.2.6). Purification of $\beta$-lactamases from strains of serological groups 3 and 9 showed that each strain produced two different enzymes, designated A and B (Cornelis \& Abraham, 1975). The two enzymes hydrolysed $\beta$-lactam substrates at different rates, were differently inhibited by $\beta$-lactam inhibitors (Cornelis, 1975; Cornelis \& Abraham, 1975), and were presumed to play different roles in resistance of the organisms to $\beta$-lactam antibiotics. A visual comparison of $\beta$-lactamases, by examining the patterns of enzymically-active bands revealed after analytical isoelectric focusing (Matthew et al., 1975), has shown that chromosomally-mediated $\beta$-lactamases are specific for genus, species and sub-species (Matthew \& Harris, 1976). The purpose of the present work was to assess the correlation between the $\beta$-lactamase isoelectric focusing patterns of various strains of $Y$. enterocolitica and the biochemical and serological groupings of the organisms.

\section{METHODS}

Strains. The strains of $Y$. enterocolitica (Table I) were classified into serotypes as described by Winblad (1967, 1968) and Wauters et al. (1971, 1972), and into biotypes according to the criteria proposed by Niléhn (1969), slightly modified by Wauters (1970). Two strains of Escherichia coli KI2 were also included: $84 \mathrm{Nx}\left(\mathrm{RY}_{3}\right)$ and NCIB9482(R-TEM).

Preparation and analytical isoelectric focusing of intracellular $\beta$-lactamases. The methods used were those described by Matthew et al. (1975).

\section{RESULTS}

The $\beta$-lactamase isoelectric focusing patterns of all the strains examined consisted of several bands (Fig. I). Some of these focused close together and were regarded as a group of bands representing a single $\beta$-lactamase. In isoelectric focusing an apparently single 
Table I. Strains of Yersinia enterocolitica from which intracellular $\beta$-lactamases were prepared

\begin{tabular}{|c|c|c|c|c|c|c|}
\hline \multirow{2}{*}{$\begin{array}{c}\text { Series } \\
\text { no. }\end{array}$} & \multirow[b]{2}{*}{ Source no.* } & \multirow{2}{*}{$\begin{array}{l}\text { Sero- } \\
\text { logical } \\
\text { group } \dagger\end{array}$} & \multirow{2}{*}{$\begin{array}{c}\text { Bio- } \\
\text { chemical } \\
\text { group } \ddagger\end{array}$} & \multirow{2}{*}{$\begin{array}{l}\text { Species of } \\
\text { isolation }\end{array}$} & \multicolumn{2}{|c|}{ Origin } \\
\hline & & & & & Worker & Country \\
\hline I & IP92 [NCTCIO462] & I & 3 & Chinchilla & Frederiksen & Denmark \\
\hline 2 & IPI IO & I & 3 & Chinchilla & Akkermans & Netherlands \\
\hline 3 & IP8 & 2 & 5 & Hare & Lucas & France \\
\hline 4 & IPI 78 & 2 & 5 & Hare & McDiarmid & U.K. \\
\hline 5 & F96-I & 2 & 5 & Hare & Fievez & Belgium \\
\hline 6 & A I 4700 & 2 & 5 & Hare & Aldova & Czechoslovakia \\
\hline 7 & W222 & 3 & 4 & Human & Wauters & Belgium \\
\hline 8 & W223 & 3 & 4 & Human & Wauters & Belgium \\
\hline 9 & W224 & 3 & 4 & Pig & Wauters & Belgium \\
\hline 10 & W230 & 3 & 4 & Pig & Wauters & Belgium \\
\hline I I & W237 & 3 & 4 & Pig & Wauters & Belgium \\
\hline 12 & W239 & 3 & 4 & Human & Wauters & Belgium \\
\hline 13 & IPI 34 ['Winblad'] & 3 & 4 & Human & Winblad & Sweden \\
\hline 14 & IP97 & 5,27 & 2 & Chinchilla & Frederiksen & Denmark \\
\hline 15 & IPI 30 & 5,27 & 2 & Monkey & Mair & U.K. \\
\hline I 6 & IPI99 & 5,27 & 2 & Chinchilla & County Vet. & California, U.S.A \\
\hline 17 & IPI 607 & 5,27 & 2 & Human & Zen-Yogi & Japan \\
\hline 18 & M77 I & 5,27 & 2 & Human & Moinet & Belgium \\
\hline 19 & IP636 [NCTCI0598] & 8 & I & Human & Sonnenwirth & U.S.A. \\
\hline 20 & IPI 453 & 8 & I & Human & Sonnenwirth & U.S.A. \\
\hline $2 I$ & IPI 628 & 8 & $\mathbf{I}$ & Human & Weaver & U.S.A. \\
\hline 22 & $1 P 2026$ & 8 & $\mathbf{I}$ & Human & Weaver & U.S.A. \\
\hline 23 & IP410 & 9 & 2 & Human & Ahvonen & Finland \\
\hline 24 & w227 & 9 & 2 & Human & Wauters & Belgium \\
\hline 25 & W228 & 9 & 2 & Human & Wauters & Belgium \\
\hline 26 & w238 & 9 & 2 & Human & Wauters & Belgium \\
\hline 27 & W244 & 9 & 2 & Human & Wauters & Belgium \\
\hline 28 & IPI 23 & 5 & I & Cow & Vallee & France \\
\hline 29 & IPIO2 & 6 & I & Human & Frederiksen & Denmark \\
\hline 30 & A ZI 523 & $16 \S$ & I & Mouse & Aldova & Czechoslovakia \\
\hline 31 & IP867 & $16 \S$ & 2 & Human & Graux & Belgium \\
\hline 32 & IP955 & 17 & I & Water & Lassen & Norway \\
\hline 33 & IP84 I & I I ,24 & $\|$ & Human & Weaver & U.S.A. \\
\hline 34 & IPIO3 & 12,26 & $\|$ & Sheep & Frederiksen & Denmark \\
\hline 35 & v.2.73(RY3) & 9 & 2 & Human & Vandepitte & Belgium \\
\hline 36 & $v .2 .73\left(R^{-}\right)$ & 9 & 2 & Human & Derived from & $.73\left(\mathrm{RY}_{3}\right)$ \\
\hline 37 & н66 & 3 & 4 & Human & Greven-Braur & Belgium \\
\hline
\end{tabular}

* Strains designated IP were received from the collection of Prof. H. H. Mollaret, Institut Pasteur, Paris.

$\uparrow$ Classified as described by Winblad $(1967$, I968) and Wauters et al. (1971, 1972).

¥ Classified according to the criteria proposed by Niléhn (I969), slightly modified by Wauters (1970).

$\S$ As suggested by the different biotypes, these two strains of serological group 16 exhibit different biochemical behaviour.

These strains do not fit exactly in any of the described biotypes.

$\beta$-lactamase commonly focuses as a group of bands, often a main band accompanied by satellites: the reason for this appearance is unknown (Matthew et al., 1975). When $\beta$-lactamases from more than one strain of a certain serological group were focused, the $\beta$-lactamase patterns for each of these strains were identical (Fig. I, serological groups I; $2 ; 3 ; 5,27 ; 8 ; 9)$.

Serological groups $I, 2,3$ and 9 . All the strains belonging to these groups had the same $\beta$-lactamase isoelectric focusing pattern, with the exception of strain $\mathrm{H} 66$ (see below). The pI 8.7 band corresponded to the broad-spectrum $\beta$-lactamase designated by Cornelis \& Abraham (1975) as type A; these authors' type B enzyme was represented by bands with pI 5.3 and $5 \cdot 7$. Cornelis \& Abraham (1975) assumed that both enzymes were chromosomally- 

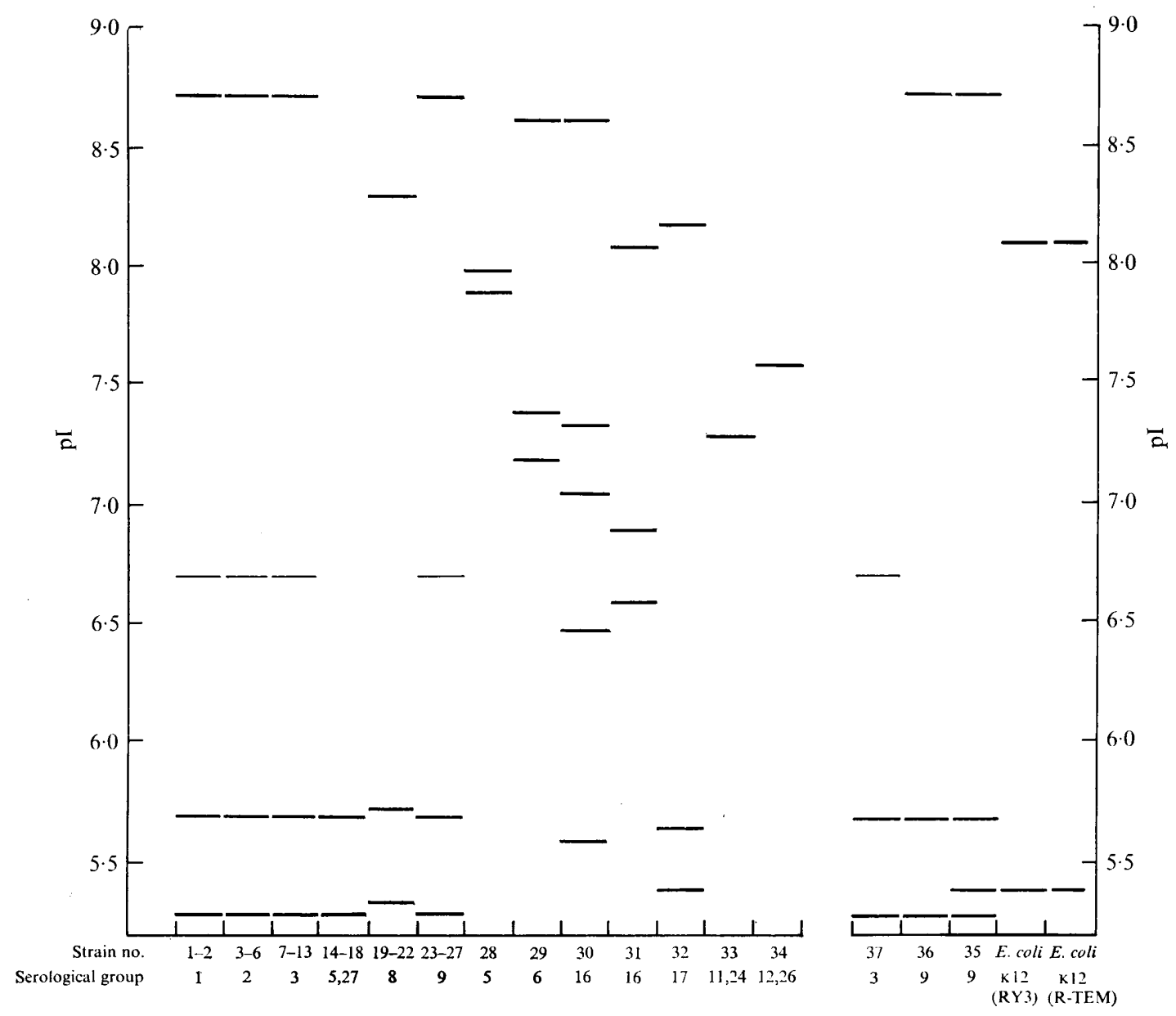

Fig. I. Analytical isoelectric focusing patterns of intracellular $\beta$-lactamases produced by Yersinia enterocolitica. Particulars of the strains are given in Table I. Plasmid RY3 was transferred from $Y$. enterocolitica $\mathrm{V}_{2}$.73(RY3) into $E$. coli $\mathrm{KI} 2$. Escherichia coli $\mathrm{KI} 2(\mathrm{R}-\mathrm{TEM})$ is a reference strain that produces the TEM-I plasmid-mediated $\beta$-lactamase (Matthew \& Hedges, 1976).

mediated and we found that none of the bands matches that of any $\beta$-lactamase known to be plasmid-mediated (Matthew \& Hedges, 1976; Matthew, unpublished observations). The TEM-I plasmid-mediated $\beta$-lactamase had a pI similar to that of Cornelis \& Abraham's B enzyme, but the $\beta$-lactamase pattern of the naturally-occurring serological group 9 strain v.2.73(RY3) (Cornelis et al., 1973; Fig. I, strain 35) indicated that the two enzymes are not identical. Strain $\mathbf{H} 66$ is atypical of group 3, since it produced no type A $\beta$-lactamase (Fig. I, strain 37). In common with other strains of groups I, 2, 3 and 9, strain H66 gave a weak $\beta$-lactamase band at pI 6.7.

Serological group 5,27. This corresponds to serological group 5 b of Cornelis (1975). Our results confirm his finding that strains of this group [except those that were indole $(-)$ ] produced only the type B $\beta$-lactamase.

Other serological groups. None of the $\beta$-lactamases produced by strains of the other serological groups studied were identical with the type A and type B enzymes, although strains from serological groups 8 and 17 gave a doublet of bands with pI values close to those of the $\mathrm{B} \beta$-lactamase. However with the exception of strain IP84I (serological group 
I I,24) and strain IPIO3 (serological group I 2,26), all strains apparently produced more than one $\beta$-lactamase. Strains of different serotype produced different $\beta$-lactamases.

\section{DISCUSSION}

Matthew \& Harris (1976) suggested that the isoelectric focusing patterns of chromosomally-mediated $\beta$-lactamases were specific for sub-species. The patterns of the A and $\mathrm{B}$ $\beta$-lactamases from $Y$. enterocolitica strains of serological groups I, 2, 3, 9 (and enzyme B for group 5,27) suggest that these strains may have a close taxonomic relationship, in spite of the biochemical differences between them. Knapp \& Thal (1972) questioned whether strains of serological group 2, usually isolated from hares, should be included in the species $Y$. enterocolitica, but our results suggest that they should.

The strains belonging to serological groups I, 2, 3,9 and 5,27 are all regularly encountered in specific hosts and all have an established pathogenicity. Apart from the $\beta$-lactamase patterns, strains of serological groups I, 2 and 3 have other features in common. Most of the strains are lysogenic (Nicolle et al., 1967): many phages liberated by group I and 3 strains plaque on group 2 strains and many phages liberated by group 2 strains plaque on strains of groups $I$ and 3 but not on representatives of other serological groups (Niléhn \& Ericson, 1969). In addition, all these strains possess the $O: 3$ antigen (Wauters et al., 197I ; Winblad, I967, I968). None of the other strains, except those belonging to group 8 , have been shown to be pathogenic. Isoelectric focusing of $\beta$-lactamases from $Y$. enterocolitica thus tends to group together the pathogenic strains, despite their wide differences in geographical origin.

In a numerical taxonomic study, Stevens \& Mair (1973) divided Y. enterocolitica into two major groups, $A$ and B. Subgroup $A_{1}$ contained strains isolated from humans, monkeys and pigs and corresponded to biotype 4 (Niléhn, I969; Wauters, I970); subgroup $A_{2}$ contained strains from various sources, including all those isolated from chinchilla; subgroup $A_{3}$ contained mainly strains isolated from hares. Group B was composed solely of hare strains of biotype 5, markedly different from group $\mathrm{A}_{3}$ strains. Our hare strains all belonged to biotype 5 , serological group 2 , and had identical $\beta$-lactamase patterns, but our sample was too small to indicate whether this pattern predominates in hare isolates. Our results cannot be compared directly with those of Stevens \& Mair (1973) because we examined different strains. But it seems that focusing of $\beta$-lactamases is a tool, additional to serological and differential biochemical tests, that should prove useful in the taxonomic classification of $Y$. enterocolitica.

We thank Janet E. Horne and Jill Sparks for technical assistance and S. R. Jones for taking the photographs.

\section{REFERENCES}

Cornelis, G. (1975). Distribution of $\beta$-lactamases $A$ and $\mathbf{B}$ in some groups of Yersinia enterocolitica and their role in resistance. Journal of General Microbiology 9r, 39I-402.

Cornelis, G. \& Abraham, E. P. (I975). $\beta$-Lactamases from Yersinia enterocolitica. Journal of General Microbiology 87, 273-284.

Cornelis, G., Wauters, G. \& Vanderhaeghe, $\boldsymbol{H}$. (1973). Présence de $\beta$-lactamase chez Yersinia enterocolitica. Annales de Microbiologie (Institut Pasteur ) 124B, 139-1 52.

Knapp, W. \& Thal, E. (1972). Die biochemische Charakterisierung von Yersinia enterocolitica (syn. 'Pasteurella X') als Grundlage eines vereinfachten O-Antigenschemas. Zentralblatt für Bakteriologie, Parasitenkunde, Infektionskrank- heiten und Hygiene (Abteilung I, Originale A) 223, 88-105.

Matthew, M. \& Harris, A. M. (1976). Identification of $\beta$-lactamases by isoelectric focusing: correlation with bacterial taxonomy. Journal of General Microbiology 94, 55-67.

Matthew, M., Harris, A. M., Marshall, M. J. \& Ross, G. W. (1975). The use of analytical isoelectric focusing for detection and identification of $\beta$-lactamases. Journal of General Microbiology 88, I69-1 78 .

Matthew, M. \& Hedges, R. W. (1976). Analytical isoelectric focusing of $\mathrm{R}$ factor-determined $\beta$ lactamases: correlation with plasmid compatibility. Journal of Bacteriology 125, 713718. 
Nicolle, P., Mollaret, H., Hamon, Y. \& Vieu, J. F. (1967). Etude lysogénique, bacteriocinogénique et lysotypique de l'espèce Yersinia enterocolitica. Annales de l'Institut Pasteur 112, 86-92.

NiLÉHN, B. (1969). Studies on Yersinia enterocolitica, with special reference to bacterial diagnosis and occurrence in human acute enteric disease. Acto pathologica et microbiologica scandinavica, Suppl. 206.

NiléHN, B. \& ERICSON, C. (I969). Studies on Yersinia enterocolitica. Bacteriophages liberated from chloroform-treated cultures. Acta pathologica et microbiologica scandinavica 75, 177-187.

Stevens, M. \& MaIR, N. S. (I973). A numerical taxonomic study of Yersinia enterocolitica strains. In Contributions to Microbiology and Immunology, vol. 2, Yersinia, Pasteurella and Francisella, pp. 17-22. Edited by S. Winblad. Basel: Karger. Wauters, G. (1970). Contribution à l'étude de Yersinia enterocolitica. Thesis, University of Louvain, Belgium.
WAUTERS, G. (1973). Correlation between ecology, biochemical behaviour and antigenic properties of Yersinia enterocolitica. In Contributions to Microbiology and Immunology, vol. 2, Yersinia, Pasteurella and Francisella, pp. 38-4I. Edited by S. Winblad. Basel: Karger.

Wauters, G., Le Minor, L. \& Chalon, A. M. (I97I). Antigènes somatiques et flagellaires des Yersinia enterocolitica. Annales de l'Institut Pasteur 120, 63I-642.

Wauters, G., Le Minor, L., Chalon, A. M. \& LASSEN, J. (1972). Supplément au schéma antigénique de Yersinia enterocolitica. Annales de l'Institut Pasteur 122, 95 I-956.

WinBlaD, S. (1967). Studies on serological typing of Yersinia enterocolitica. Acta pathologica et microbiologica scandinavica, Suppl. 187, I 5.

WINBLAD, S. (I968). Studies on O-antigen factors of Yersinia enterocolitica. In International Symposium on Pseudotuberculosis, Symposia Series in Immunobiological Standardisation, vol. 9, pp. 337342. Basel: Karger. 